\title{
POTENSI KECELAKAAN KERJA PADA PERIKANAN BAGAN APUNG DI PPN PALABUHANRATU, JAWA BARAT
}

\section{THE POTENTIAL OF WORK ACCIDENT ON THE LIFTNET FISHERIES IN PPN PALABUHANRATU, WEST JAVA}

\author{
Muhamad Rizki Riantoro', Budhi Hascaryo Iskandar ${ }^{2}$, Fis Purwangka ${ }^{2}$ \\ ${ }^{1}$ Perum Perikanan Indonesia, Jakarta \\ ${ }^{2}$ Departemen Pemanfaatan Sumberdaya Perikanan, \\ Fakultas Perikanan dan Ilmu Kelautan, Institut Pertanian Bogor \\ Korespondensi: fis@psp-ipb.org
}

\begin{abstract}
This study focused on lift net fishery activity on its boat carrier. The activity on this transports is the most dangerous potential risk. The limited work area on the boat, with a large number of passengers and added weight of the quantity of goods transported can cause a high chance of accidents. The condition is also exacerbated by the situation on transports that no passenger uses safety equipment or personal protective equipment (PPE), and also the unavailability of these equipment in the boat. The study were aimed to identify the potential hazard or risk during operating of the bagan apung, and to identify the fishermen knowledge in working safety. The method used in this study is a case study method on the potential for work accident in boat carrier and lift net in Palabuhanratu. Primary data were obtained by interview through questionnaire. Secondary data were obtained through literature study concerning fishermen safety occupational. Job Safety Analysis (JSA) was used to examine the working method and the potential hazard at every step of the boat carrier and the bagan apung fishery activity. The result showed that, (1) based on Job Safety Analysis the risk arising were categorized into 3 of accident which were not severe $(88 \%)$, severe $(12 \%)$ and very severe $(0 \%) ;(2)$ The fishermen having knowledge were categorized as good enough regarding occupational safety and procedures work on a boat. However, lack of awareness of the relevant agencies and fishermen in the management and implementation of work safety procedures in PPN Palabuhanratu had not been implemented properly.
\end{abstract}

Keyword: bagan apung, job safety, Palabuhanratu bay, ship carrier

\begin{abstract}
ABSTRAK
Fokus perhatian pada penelitian ini adalah aktivitas perikanan bagan di atas kapal angkutnya. Aktivitas pada kapal angkut inilah yang paling banyak memiliki potensi risiko berbahaya. Kecilnya area pada kapal angkut, dengan jumlah penumpang yang banyak dan ditambah dengan berat jumlah barang yang diangkut tersebut dapat menyebabkan peluang kecelakaan yang tinggi. Kondisi tersebut juga diperparah dengan situasi di atas kapal angkut yang tidak terdapat seorang penumpang pun yang menggunakan alat keselamatan dan APD (Alat Perlindungan Diri), dan juga tidak tersedianya alatalat tersebut di dalam kapal. Penelitian ini bertujuan untuk mengidentifikasi risiko kerja pada kegiatan perikanan bagan apung, dan mengidentifikasi pengetahuan nelayan bagan apung terhadap keselamatan kerja.. Metode yang digunakan dalam penelitian ini adalah metode studi kasus pada potensi kecelakaan kerja di kapal angkut dan bagan apung di Palabuhanratu. Data primer didapatkan dari hasil pengamatan langsung dan wawancara terhadap beberapa pihak terkait dengan keselamatan kerja nelayan. Data sekunder diperoleh dari berbagai sumber seperti literatur, dokumen serta arsip yang ada pada instansi terkait. Pengolahan data dilakukan dengan analisis keselamatan kerja (Job Safety Analysis/JSA). Hasil penelitian ini menunjukkan, (1) berdasarkan JSA diperoleh bahwa risiko yang timbul terbagi dalam 3 kategori yakni kategori tidak parah $(88 \%)$, parah $(12 \%)$ dan sangat parah $(0 \%)$; (2) nelayan bagan memiliki pengetahuan yang dikategorikan cukup baik mengenai keselamatan kerja dan prosedur kerja di kapal.
\end{abstract}

Kata kunci: bagan apung, kapal angkut, keselamatan kerja, PPN Palabuhanratu 


\section{PENDAHULUAN}

\section{Latar belakang}

Perikanan bagan apung merupakan salah satu alat tangkap yang dominan dan melibatkan banyak nelayan di PPN Palabuhanratu. Nelayan bagan masih belum menjadikan aspek keselamatan menjadi salah satu pertimbangan penting dalam operasi penangkapan ikan pada perikanan bagan, khususnya di Pelabuhan Perikanan Nusantara (PPN) Palabuhanratu, Jawa Barat. Jumlah nelayan yang bekerja pada perikanan bagan umumnya berjumlah 1-2 orang. Fokus perhatian pada penelitian ini adalah aktivitas perikanan bagan di atas kapal angkutnya. Aktivitas pada kapal angkut inilah yang paling banyak memiliki potensi risiko berbahaya. Kapal angkut yang digunakan dapat mengangkut 10-12 orang nelayan bagan, $2 \mathrm{kru}$ kapal, serta terdapat penumpang selain nelayan bagan yang jumlahnya dapat lebih dari 5 orang yang ikut berlayar. Kecilnya area pada kapal angkut, dengan jumlah penumpang yang banyak dan ditambah dengan berat jumlah barang yang diangkut tersebut dapat menyebabkan peluang kecelakaan yang tinggi. Kondisi tersebut juga diperparah dengan situasi di atas kapal angkut yang tidak terdapat seorang penumpang pun yang menggunakan alat keselamatan dan APD (Alat Perlindungan Diri), dan juga tidak tersedianya alat-alat tersebut di dalam kapal yang seharusnya dilengkapi apabila hendak melakukan aktivitas pelayaran. Begitu pula dengan alat tangkap bagan. Bagan yang letaknya di tengah perairan dengan personil nelayan yang hanya 1 orang, apabila terjadi kecelakaan kerja atau pun kecelakaan akibat kondisi cuaca dan perairan yang memiliki gelombang laut cukup kuat maka tidak akan ada yang mampu memberikan bantuan karena terbatasnya komunikasi dengan nelayan tersebut.

Peluang tingkat kecelakaan tersebut dapat juga disebabkan oleh sikap, keterampilan dan pengetahuan nelayan yang rendah tentang keselamatan kerja di laut. Peran aktif pemerintah setempat dalam penanganan saat kecelakaan maupun setelah kecelakaan terjadi serta tindakan pencegahan lainnya dari beberapa kejadian kecelakaan nelayan di Palabuhanratu sampai saat ini belum terlihat (Purwangka 2013). Kondisi perairan Teluk Palabuhanratu, dilihat dari sisi lingkungan perairan, lebih banyak dipengaruhi oleh kondisi oseanografi
Samudera Hindia seperti adanya musim. Wilayah perairan selatan Jawa tersebut hempasan gelombangnya cukup kuat dan tiupan angin pun di perairan tersebut cukup kuat sehingga tinggi gelombang cukup tinggi dan sulit diduga (Wyrtki 1961).

Data di Indonesia, sepanjang Desember 2008 - Maret 2009, sebanyak 18 kapal tenggelam. Dari tragedi itu, sebanyak 43 orang meninggal dunia, 386 orang dinyatakan hilang, dan 105 orang selamat atau menderita luka-luka, baik fisik maupun psikis (Ant 2009). Risiko kecelakaan kerja yang banyak terjadi adalah pada aktivitas pengoperasian alat tangkap. Faktor penyebab utama adalah faktor kesalahan manusia atau nelayan itu sendiri yang disebut human error sebesar 43.67\% (FAO 2009). Namun dalam meningkatkan faktor kualitas nelayan itu sendiri, kecelakaan dapat dihindari atau diminimalkan. Adapun cara untuk meminimalisir terjadinya kecelakaan ialah ketika pengoperasian alat tangkap dan kapal perlu didukung adanya aturan atau SOP (Standar Operation Procedure) terhadap kerja nelayan ketika melakukan aktivitas tersebut.

Karakteristik pekerjaan di atas kapal angkut dan bagan apung menuntut kepedulian terhadap keselamatan baik oleh awak kapal maupun pemilik kapal dan penguasaan kompetensi yang berkaitan dengan keselamatan bagi awak kapal. Kesadaran akan keselamatan tersebut terlihat kurang mendapat respon positif oleh nelayan bagan apung maupun pemilik kapal angkut di PPN Palabuhanratu. Kurangnya informasi, ketidaktahuan dan kurangnya keterampilan dapat menimbulkan risiko hingga kecelakaan dalam bekerja. Berdasarkan hal tersebut, perlu adanya identifikasi mengenai keselamatan kerja nelayan bagan apung dengan melihat seluruh aktivitas penangkapan alat tangkap bagan apung di Palabuhanratu, Sukabumi. Tujuan dari penelitian ini adalah 1) mengidentifikasi risiko kerja atau potensi bahaya pada kegiatan perikanan bagan apung di PPN Palabuhanratu dan 2) mengidentifikasi pengetahuan nelayan bagan apung terhadap keselamatan kerja di PPN Palabuhanratu.

\section{METODE PENELITIAN}

Penelitian ini dilaksanakan pada bulan Januari sampai dengan bulan September 2014. Pengambilan data dilakukan pada bulan April 2014 di PPN Palabuhanratu, 
Kabupaten Sukabumi, Jawa Barat. Metode yang digunakan dalam penelitian ini adalah metode studi kasus pada potensi kecelakaan kerja di kapal angkut dan bagan apung di Palabuhanratu. Metode ini digunakan karena menurut beberapa sumber, tingginya angka kecelakaan di laut yang terjadi di Palabuhanratu tetapi banyak yang tidak tercatat oleh instansi setempat atau tidak dilaporkan. Maka dari itu perlu adanya sebuah studi secara langsung di lapangan untuk mengetahui potensi yang menyebabkan timbulnya kasus tersebut. Penelitian ini menggunakan dua jenis data, yaitu data primer dan data sekunder. Data primer didapatkan dari hasil wawancara menggunakan kuesioner terhadap beberapa pihak terkait dengan keselamatan kerja yaitu syahbandar, staf PPN Palabuhanratu, polisi air, staf unit kesehatan nelayan, serta beberapa tokoh nelayan di sekitar PPN Palabuhanratu. Data ini dilengkapi juga dengan pengamatan langsung aktivitas di atas kapal angkut bagan sebanyak 3 kapal dan operasi penangkapan ikan bagan apung dengan cara mengikuti operasi penangkapan sebanyak 3 kali trip. Responden dalam penelitian ini adalah 30 orang nelayan bagan apung yang menggunakan 3 buah kapal angkut. Ketiga kapal tersebut juga menjadi objek dalam penelitian ini. Data sekunder merupakan data penunjang yang diperoleh dari berbagai sumber seperti literatur, dokumen serta arsip yang ada pada instansi terkait.

Objek yang digunakan dalam penelitian ini adalah kapal angkut dan bagan apung yang beroperasi di wilayah perairan Palabuhanratu, Sukabumi. Alat yang digunakan pada penelitian ini antara lain kuesioner, handycam, kamera digital, perangkat komputer, alat tulis dan peralatan lainnya yang digunakan dalam membantu pengumpulan data dan pengolahan data. Data yang dikumpulkan diolah dengan tabulasi dan perhitungan persentase terhadap hasil jawaban nelayan pada kuesioner yang digunakan. Hasil pengolahan data ini selanjutnya dijadikan bahan analisis. Analisis yang digunakan meliputi analisis deskriptif terhadap unit penangkapan bagan dan analisis keselamatan kerja (JSA) terkait keselamatan kerja nelayan bagan.

\section{Analisis keselamatan kerja (Job Safety Analysis - JSA)}

JSA adalah suatu cara yang digunakan untuk memeriksa metode kerja dan menentukan bahaya yang sebelumnya telah diabaikan dalam merencanakan pabrik atau gedung dan di dalam rancang bangun mesin-mesin, alat-alat kerja, material, lingkungan tempat kerja, dan proses aktivitas kerja (Soeripto 1997). Proses kerja yang diterapkan pada JSA di dalam penelitian ini yaitu keselamatan kerja nelayan pada aktivitas di atas kapal angkut dan aktivitas penangkapan pada alat tangkap bagan apung.

Langkah pekerjaan dicatat di kolom sebelah kiri, potensi bahaya dituliskan pada kolom tengah tabel, diberi nomor untuk mencocokkan dengan langkah pekerjaan, seperti disajikan padaTabel 1.

Identifikasi risiko bahaya dimulai dengan melakukan identifikasi seluruh sumber bahaya pada area konsekuensi atau dampak. Menyusun rutan aktivitas yang benar saat melakukan sebuah identifikasi dibutuhkan untuk memastikan bahwa tidak ada area lain yang terlewatkan. Seluruh aktivitas tersebut akan diperinci kembali dengan mengurutkan seluruh tahapan aktivitas dengan menuliskan kegiatan kegiatan yang dilakukan pada proses tahapan tersebut. Aktivitas tersebut dijadikan sebagai dasar untuk menanyakan pertanyaan dengan cara yang imajinatif tentang apa yang mungkin terjadi dan bagaimana hal itu dapat terjadi sesuai kelas yang dibagi dalam kemungkinan dan konsekuensi dari kecelakaan (Cross 1998). Berikut disajikan dalam Tabel 2 dan Tabel 3.

Tabel 1. Lembar kerja analisis keselamatan kerja

\begin{tabular}{cccc}
\hline No & Urutan kegiatan & Potensi bahaya & Tindakan pencegahan \\
\hline 1. & $\ldots$ & $\ldots$ & $\ldots$ \\
2. & $\ldots$ & $\ldots$ & $\ldots$ \\
3. & $\ldots$ & $\ldots$ & $\ldots$ \\
$\ldots$ & $\ldots$ & $\ldots$ & $\ldots$ \\
\hline
\end{tabular}

Sumber : CCOHS (2008) 
Tabel 2. Kemungkinan dari kecelakaan

\begin{tabular}{ccc}
\hline Kelas & Peluang & Peluang terjadi \\
\hline A & Besar & 1 kali dalam 1 tahun \\
B & Sedang & 1 kali dalam 10 tahun \\
C & Kecil & 1 kali dalam 100 tahun \\
\hline
\end{tabular}

Sumber : IMO (2017)

Tabel 3. Konsekuensi dari kecelakaan

\begin{tabular}{|c|c|c|c|}
\hline Kelas & Kecelakaan & Deskripsi & Example \\
\hline 1 & Tidak parah & Menyebabkan cedera; tidak fatal & $\begin{array}{l}\text { Kecelakaan yang menimbulkan } \\
\text { cedera tetapi tidak sampai ada } \\
\text { korban jiwa }\end{array}$ \\
\hline 2 & Parah & $\begin{array}{l}\text { Menyebabkan beberapa cedera/ } \\
\text { luka dan korban jiwa }\end{array}$ & $\begin{array}{l}\text { Kecelakaan yang menyebabkan } \\
\text { cedera berat, hingga } 1 \text { sampai } 2 \\
\text { orang korban jiwa dan kerusakan } \\
\text { kapal. }\end{array}$ \\
\hline 3 & $\begin{array}{l}\text { Sangat } \\
\text { parah }\end{array}$ & $\begin{array}{l}\text { Menyebabkan korban jiwa/ } \\
\text { meninggal }\end{array}$ & $\begin{array}{l}\text { Kecelakaan besar, mengakibatkan } \\
3 \text { sampai seluruh awak kapal } \\
\text { dapat meninggal dunia atau } \\
\text { hilangnya kapal. }\end{array}$ \\
\hline
\end{tabular}

Sumber : IMO (2017)

\section{HASIL DAN PEMBAHASAN}

\section{Analisis keselamatan kerja (Job Safety Analysis - JSA)}

Kapal, alat tangkap, dan nelayan merupakan tiga faktor yang mendukung keberhasilan suatu operasi penangkapan ikan. Aktivitas penangkapan ikan terutama di laut adalah kegiatan yang berisiko tinggi, sehingga kapal perikanan dapat menjadi lingkungan kerja yang memiliki potensi bahaya. Faktor keselamatan kapal maupun nelayan harus diperhatikan dan langkahlangkah pencegahan harus dilakukan untuk meminimumkan atau bahkan menghilangkan potensi risiko bahaya atau kecelakaan tersebut untuk menunjang kesuksesan suatu operasi penangkapan ikan. Definisi kecelakaan adalah kejadian tidak terduga dan tidak diharapkan yang dapat menimbulkan cedera, cacat, bahkan kematian sebagai akibat kecelakaan kerja (Suma'mur 1995).

Menurut Adi et al. (2008), kapal laut sebagai bangunan terapung yang bergerak menggunakan daya dorong sebuah mesin pada kecepatan yang bervariasi untuk melintasi berbagai daerah pelayaran dalam kurun waktu tertentu. Kapal dapat mengalami berbagai permasalahan yang dapat disebabkan oleh beberapa faktor yaitu cuaca, keadaan alur pelayaran, manusia, kapal dan lainnya yang belum dapat diduga oleh kemampuan manusia dan akhirnya menimbulkan gangguan pelayaran dari kapal.

Gangguan pelayaran pada dasarnya dapat berupa gangguan yang dapat langsung diatasi, bahkan perlu mendapatkan bantuan langsung dari pihak tertentu, atau gangguan yang mengakibatkan nahkoda dan seluruh anak buah kapal harus terlibat baik untuk mengatasi gangguan tersebut serta harus meninggalkan kapal. Keadaan gangguan pelayaran tersebut sesuai dengan situasi dapat dikelompokkan menjadi keadaan darurat yang didasarkan pada jenis kejadian itu sendiri, sehingga sebuah gangguan dalam pelayaran secara garis besar dapat disusun menjadi tubrukan, kebakaran/ledakan, kandas, kebocoran/tenggelam, orang jatuh ke laut, dan pencemaran.

Keadaan darurat di kapal dapat merugikan nahkoda, anak buah kapal, pemilik kapal, dan lingkungan laut. Kondisi keadaan darurat perlu dipahami sebaik mungkin. Hal ini dapat ditempuh dengan memiliki kemampuan dasar untuk dapat mengidentifikasi tanda-tanda keadaan darurat agar situasi yang demikian dapat diatasi oleh seluruh awak kapal maupun melakukan kerja sama dengan pihak-pihak yang terkait.

Kapal angkut bagan apung yang diteliti melakukan pelayaran dimulai pukul 
15.00 WIB untuk mengantar nelayan menuju bagan apung masing-masing. Waktu tempuh pelayaran selama 2-3 jam hingga selesai mengantarkan seluruh nelayan bagan berjumlah 10 orang yang merupakan langganannya. Aktivitas bagan, secara urut disampaikan pada Tabel 4.

Tabel 4. Aktivitas bagan apung di Palabuhanratu

\begin{tabular}{cl}
\hline No & \multicolumn{1}{c}{ Urutan kegiatan } \\
\hline 1 & Persiapan di darat \\
2 & Pemindahan (loading) barang ke atas kapal angkut \\
3 & Berlayar menuju daerah penangkapan ikan (navigasi) \\
4 & Pemindahan alat tangkap bagan ke daerah penangkapan ikan (fishing ground) dengan \\
& kapal angkut \\
5 & Pemindahan (loading) barang ke alat tangkap bagan \\
6 & Persiapan alat tangkap \\
7 & Pengoperasian alat tangkap, penurunan jaring (setting) pertama \\
8 & Pengangkatan jaring (hauling) alat tangkap pertama \\
9 & Penanganan hasil tangkapan pertama \\
10 & Penurunan jaring (setting) kedua dan seterusnya \\
11 & Pengangkatan jaring (hauling) alat tangkap kedua dan seterusnya \\
12 & Penanganan hasil tangkapan kedua dan seterusnya \\
13 & Pemindahan (loading) hasil tangkapan dan barang ke atas kapal angkut \\
14 & Berlayar menuju pelabuhan asal (fishing base) \\
15 & Unloading hasil tangkapan dan barang ke dermaga \\
\hline
\end{tabular}

Sumber : Hasil observasi peneliti

Urutan langkah kerja dalam setiap aktivitas operasi penangkapan ikan akan dikelompokkan dan kemudian dianalisis potensi bahaya yang mungkin timbul, serta memberikan saran dan masukan tentang tindakan apa yang perlu dilakukan untuk menghilangkan atau meminimalisir potensi bahaya tersebut. Berikut penguraian analisis keselamatan kerja dalam masingmasing tahap pra operasi, tahap operasi, dan tahap pasca operasi.

\section{Tahap pra operasi}

Persiapan di darat

Pemilik kapal angkut beserta ABK mempersiapkan kebutuhan melaut dan nelayan bagan apung menyiapkan kebutuhan perbekalan seperti air tawar, bahan makanan, solar, oli, lampu, genset dan persiapan lainnya.. Nelayan mempersiapkan perbekalan dirumahnya masing-masing. Perbekalan yang sudah dipersiapkan kemudian dimasukkan ke dalam ember kaleng cat bekas sebagai wadah penyimpanan seluruh perlengkapan tersebut.

Penggunaan ember kaleng cat bekas memiliki keunggulan karena dapat ditutup rapat sehingga perlengkapan yang dibawa tidak akan basah apabila terkena air hujan ataupun air laut jika terjatuh ke laut. Selain itu ember kaleng cat bekas ini dapat juga berfungsi sebagai pelampung atau alat pelindung diri pengganti dari life jacket yang digunakan apabila nelayan tercebur ke laut. Nelayan membawa wadah ember kaleng cat yang telah lengkap berisi dengan perbekalan ke dermaga sambil menunggu pemberangkatan menggunakan kapal angkut menuju fishing ground masingmasing sekitar pukul 15.00 WIB. Perjalanan menuju fishing ground memiliki waktu tempuh selama 2-3 jam.

Kategori kecelakaan parah terdapat pada kegiatan nomor 3 (tiga) yaitu saat persiapan BBM dan oli samping, dengan potensi bahaya terjadi kecelakaan pada saat pengangkutan BBM dengan menggunakan sepeda motor. Kejadian tersebut dapat dicegah dengan solusi memakai alat angkut yang aman seperti gerobak beroda atau keranjang besi khusus 
untuk membawa jirigen yang ditempelkan pada motor sehingga mengurangi potensi terjatuh dan tumpah. Potensi bahaya dengan kemungkinan yang besar terjadi pada aktivitas nomor 4 (empat) yaitu saat persiapan dan cek mesin oleh nahkoda. Potensi bahaya tersebut adalah kunci pas dan peralatan lain untuk pengecekan mesin mengenai anggota tubuh. Walaupun hal ini sering terjadi namun kecelakaan tersebut masuk ke dalam kategori yang tidak parah. Kejadian tersebut dapat dicegah dengan pemakaian APD oleh nahkoda atau pihak lain yang bertugas untuk melakukan persiapan dan cek mesin seperti sarung tangan dan sepatu safety (safety boots). Total urutan kegiatan pada aktivitas persiapan di darat terdapat 5 kegiatan dengan 9 potensi bahaya. Kategori kecelakaannya terbagi atas 8 kategori kecelakaan tidak parah dan 1 kategori kecelakaan parah.

\section{Pemindahan (loading) ke atas kapal angkut}

Pemindahan perlengkapan ke atas kapal angkut (loading) menggunakan alat bantu berupa katrol dan tali agar mempermudah pemindahan barang. Kategori kecelakaan parah terdapat pada kegiatan nomor 2 (dua) yaitu saat pemindahan genset dan jirigen berisi peralatan bagan ke atas kapal, dengan potensi bahaya terjadi pada saat pemindahan mesin genset dapat terjatuh dan mengenai anggota tubuh. Kejadian tersebut dapat dicegah dengan solusi memakai alat pemindahan yang aman dan membersihkan jalan yang akan dilalui sehingga tidak licin. Total urutan kegiatan pada aktivitas pemindahan (loading) ke atas kapal angkut terdapat 3 kegiatan dengan 11 potensi bahaya. Kategori kecelakaannya terbagi atas 10 kategori kecelakaan tidak parah dan 1 kategori kecelakaan parah.

\section{Berlayar menuju daerah penangkapan ikan (navigasi)}

Peralatan dan kebutuhan melautyang telah dipindahkan ke atas kapal kemudian dilanjutkan menuju daerah penangkapan atau fishing ground. Risiko bahaya pada aktivitas ini adalah pada saat juru mudi mengarahkan kapal keluar dari kolam pelabuhan. Posisi kapal yang sebelumnya bersandar pada kolam pelabuhan terhambat jalur keluarnya dengan kapalkapal lainnya yang juga sedang bersandar di pelabuhan. Area yang sempit tersebut membuat kapal angkut bagan yang hendak keluar pelabuhan mengenai dinding kolam pelabuhan dan menabrak kapal lainnya untuk bisa memposisikan kapal angkut keluar dari pelabuhan. Kondisi seperti ini dapat mengakibatkan kapal terbalik maupun menimbulkan kebocoran pada bagian badan kapal.

Kategori kecelakaan parah terdapat pada kegiatan nomor 3 (tiga) yaitu saat nahkoda mengarahkan kapal keluar dari kolam pelabuhan, dengan potensi bahaya kapal bocor atau tenggelam akibat terbentur badan kapal yang lain dan kapal hilang arah saat pelayaran. Kejadian tersebut dapat dicegah dengan solusi melakukan pengecekan rutin terhadap kelayakan kapal, dan membawa alat bantu navigasi berupa GPS (Global Positioning System) atau peta lokasi. Total urutan kegiatan pada aktivitas berlayar menuju daerah penangkapan (navigasi) terdapat 4 kegiatan dengan 15 potensi bahaya. Kategori kecelakaannya terbagi atas 13 kategori kecelakaan tidak parah dan 2 kategori kecelakaan parah.

Pemindahan alat tangkap bagan ke daerah penangkapan ikan (fishing ground) dengan kapal angkut

Bagan apung yang dioperasikan oleh nelayanberadadisekitarTelukPalabuhanratu yang ditempuh dalam 2-3 jam perjalanan atau sekitar \pm 25 mil laut dari fishing base (PPN Palabuhanratu). Alat tangkap bagan apung pada penelitian ini dapat dipindahpindahkan posisinya. Perpindahan bagan apung tergantung dari bagan apung lainnya karena nelayan memindahkan alat tangkapnya berdasarkan informasi atau melihat jumlah hasil tangkapan nelayan bagan yang lain. Apabila hasil tangkapan salah satu nelayan banyak, maka nelayan bagan tersebut akan memberikan informasi kepada nelayan lainnya, kemudian nelayan bagan yang lain akan mengikuti ke tempat nelayan yang memperoleh hasil tangkapan banyak tersebut. Perpindahan bagan apung tersebut ditarik oleh kapal angkut bagan apung, tetapi perpindahannya tidak akan terlalu jauh pengoperasiannya masih tetap di sekitar Teluk Palabuhanratu. Alat tangkap bagan apung dipindahkan oleh kapal langganannya. Sebelum bagan apung dipindahkan, nelayan bagan apung sudah menghubungi nelayan pemilik bagan apung dengan kapal langganannya beberapa hari sebelumnya untuk mengkonfirmasi pemindahan alat tangkapnya.

Alat yang digunakan untuk 
pemindahan bagan apung yaitu berupa tali tambat kapal yang berbahan PE berukuran besar yang memiliki diameter sekitar $5 \mathrm{~cm}$. Tali PE berukuran besar ini berfungsi untuk menaikkan jangkar bagan dan menarik bagan hingga ke daerah penangkapan yang sesuai. Daerah penempatan bagan apung yang dipindahkan biasanya berdasarkan pada panjang jangkar yang dimiliki atau terletak pada perairan dangkal atau di daerah teluk dengan kedalaman rata-rata sekitar $10 \mathrm{~m}$.

Kategori kecelakaan parah terdapat pada kegiatan nomor 4 (empat) yaitu saat kapal menarik bagan apung ke daerah penangkapan. Terdapat dua potensi bahaya yang akan terjadi yakni kapal kehilangan arah serta kapal angkut atau bagan apung dapat terbalik/ tenggelam. Kejadian tersebut dapat dicegah dengan solusikapal angkut dilengkapi dengan GPS (Global Positioning System) atau peta lokasi setempat, serta melakukan pemeriksaan rutin terkait kondisi kapal angkut dan bagan apung. Total urutan kegiatan pada aktivitas pemindahan alat tangkap bagan ke daerah penangkapan ikan (fishing ground) dengan kapal angkut terdapat 4 kegiatan dengan 15 potensi bahaya. Kategori kecelakaannya terbagi atas 13 kategori kecelakaan tidak parah dan 2 kategori kecelakaan parah.

\section{Pemindahan (loading) barang ke alat tangkap bagan apung}

Tahap pemindahan perlengkapan ke alat tangkap bagan apung merupakan kegiatan yang dapat dikatakan berbahaya dan sangat minim peralatan keselamatan. Nelayan yang telah sampai pada alat tangkapnya akan berpindah ke atas bagan dengan membawa seluruh perlengkapan yang dibawanya yaitu genset, jirigen BBM, jirigen air tawar dan ember cat bekas yang berisi lampu, perbekalan,dan lain-lain.

Kategori kecelakaan parah terdapat pada kegiatan nomor 2 (dua) yaitu saat pemindahan genset dan jirigen ke alat tangkap bagan apung, dengan potensi bahaya mesin genset atau jirigen terjatuh mengenai anggota tubuh. Kejadian tersebut dapat dicegah dengan solusi menggunakan alat bantu pengangkutan seperti katrol atau lintasan pemindahan. Total urutan kegiatan pada aktivitas pemindahan (loading) ke alat tangkap bagan apung terdapat 2 kegiatan dengan 6 potensi bahaya. Kategori kecelakaannya terbagi atas 5 kategori kecelakaan tidak parah dan 1 kategori kecelakaan parah.

Persentase risiko kerja pada tahap pra operasi bagan apung

Tahap pra operasi bagan apung terdiri dari aktivitas persiapan di darat, pemindahan (loading) barang ke atas kapal angkut, berlayar menuju daerah penangkapan ikan (navigasi), pemindahan alat tangkap bagan ke daerah penangkapan ikan (fishing ground) dengan kapal angkut, hingga pemindahan (loading) barang ke alat tangkap bagan. Berdasarkan analisis yang dilakukan dari aktivitas pada tahap pra operasi tersebut memiliki kategori kecelakaan $86 \%$ tidak parah, $14 \%$ parah dan untuk kategori sangat parah pada tahap ini tidak ada (Gambar 1). Hal ini menunjukkan bahwa aktivitas-aktivitas pada tahap pra operasi bagan apung masih dirasa kurang aman, maka dari itu perlu adanya upaya untuk meningkatkan keselamatan kerja pada aktivitas ini para ABK kapal angkut bagan seharusnya menggunakan Alat Pelindung Diri (APD) seperti sarung tangan, safety boots, dan lain lain.

Berdasarkan SOLAS (1974) terdapat peraturan yang mengatur mengenai semua peralatan yang digunakan oleh suatu individu di tempat kerja untuk melindungi individu dari satu atau lebih risiko kesehatan dan keselamatan. Peralatan dan bahan yang digunakan harus diperhatikan kelayakan dan perawatannya, dimana peralatan dan bahan yang akan digunakan sebagai alat pelindung diri merupakan penunjang keberhasilan aktivitas bagan apung untuk menghasilkan hasil tangkapan yang optimal tanpa adanya risiko kecelakaan. Nelayan sebaiknya melengkapi dirinya dengan perlengkapan perlindungan diri yang harus lengkap mulai dari alat perlindungan kepala, sarung tangan, jas hujan (warepack), life jacket dan sepatu. 


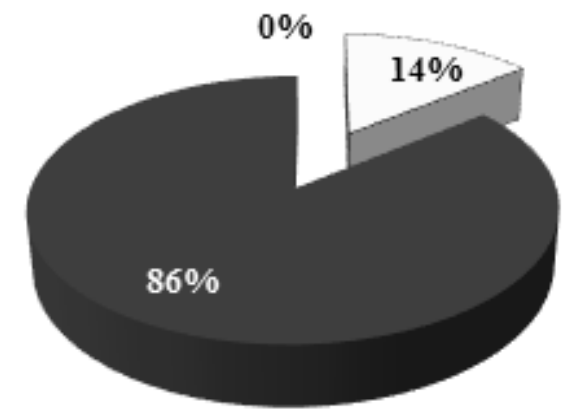

- Sangat parah $\square$ Parah Iidak parah

Gambar 1. Pelabelan komposisi habitat bentik Persentase risiko kerja pada tahap pra operasi bagan apung dari 18 kegiatan

\section{Tahap operasi}

\section{Persiapan alat tangkap}

Persiapan alat tangkap dilakukan ketika nelayan telah sampai di fishing ground. Nelayan melakukan persiapan selama $\pm 1,5$ jam untuk menyusun letak genset dan keranjang, pengisian bahan bakar pada genset, memasang lampu bagan, memasang instalasi listrik pada genset untuk menghidupkan lampu bagan. Risiko bahaya yang timbul pada kegiatan ini yaitu ABK dapat tercebur kelaut dan dapat tersengat aliran listrik.

Kategori kecelakaan parah dan memiliki kemungkinan terjadi yang besar terdapat pada aktivitas nomor 5 (lima) yaitu saat pemasangan 6 buah lampu bagan, dengan potensi bahaya nelayan dapat tersengat aliran listrik. Kejadian tersebut dapat dicegah dengan solusi memakai APD dan alas kaki agar terhindar dari sengatan listrik. Total urutan kegiatan pada aktivitas pemindahan (loading) ke alat tangkap bagan apung terdapat 5 kegiatan dengan 11 potensi bahaya, dalam kategori kecelakaannya terbagi atas 9 kategori kecelakaan tidak parah dan 2 kategori kecelakaan parah.

Pengoperasian alat tangkap, penurunan jaring (setting).

Proses penangkapan ikan dengan bagan apung dimulai dengan penurunan jaring atau setting alat. Penurunan bingkai bambu beserta jaring dilakukan sebelum hari gelap, jaring diturunkan sekitar pukul 18.00 WIB. Penurunan jaring dilakukan dengan mengulur tali pada 4 sisi bingkai jaring yang bertumpu pada sebuah roller bambu, kemudian jaring diturunkan pada kedalaman tertentu. Lampu bagan dinyalakan agar menarik perhatian ikan target yang mayoritas merupakan ikan yang memiliki sifat fototaksis positif. Ikan target akan berkumpul di sekitar lampu. Sumber energi listrik diperoleh dari mesin genset. Lampu bagan diturunkan mendekati perairan dengan jarak $\pm 1,5 \mathrm{~m}$ antara lampu dan air laut, sehingga cahaya lampu akan menerangi perairan dan masuk menembus kolom perairan. Padaaktivitas pengoperasian alat tangkap serta penurunan jaring ini memiliki risiko bahaya seperti tangan dapat terluka dan dapat mengakibatkan sakit punggung akibat menurunkan jaring menggunakan roller bambu yang berat.

Kategori kecelakaan parah tidak terdapat pada aktivitas pengoperasian alat tangkap serta penurunan jaring, namun memiliki potensi bahaya dengan kemungkinan terjadi yang besar terdapat pada kegiatan nomor 1 dan 2 yaitu tangan terluka pada saat pelepasan jaring dan penurunan bingkai jaring dengan roller. Kejadian tersebut dapat dicegah dengan solusi memakai APD berupa sarung tangan. Total urutan kegiatan pada aktivitas pengoperasian alat tangkap serta penurunan jaring terdapat 2 kegiatan dengan 6 potensi bahaya. Kategori kecelakaan seluruhnya termasuk ke dalam kategori kecelakaan tidak parah.

\section{Pengangkatan jaring (hauling) alat tangkap}

Dalam pengoperasiannya nelayan alat tangkap bagan hanya menunggu dan melakukan pengamatan melalui rumah bagan untuk melihat adanya tandatanda keberadaanikan di sekitar bagan. Setelah diperkirakan ikan target telah banyak berkumpul di sekitar lampu, maka lampu akan dimatikan satu persatu dan menyisakan satu lampu agar ikan terfokus berkumpul pada satu lampu saja. Langkah selanjutnya dilakukan proses pengangkatan jaring (hauling) dengan memutar roller untuk menarik bingkai jaring ke permukaan. 
Proses ini memiliki risiko bahaya seperti tangan ABK dapat terluka.

Kategori kecelakaan parah tidak terdapat pada aktivitas pengangkatan jaring (hauling), namun memiliki potensi bahaya dengan kemungkinan terjadi yang besar terdapat pada kegiatan nomor 1 dan 2 yaitu tangan terluka pada saat pengangkatan bingkai jaring dengan roller dan pengikatan jaring ke bagan. Kejadian tersebut dapat dicegah dengan solusi memakai APD berupa sarung tangan. Total urutan kegiatan pada aktivitas pengangkatan jaring (hauling) terdapat 2 kegiatan dengan 8 potensi bahaya, dalam kategori kecelakaan seluruhnya termasuk ke dalam kategori kecelakaan tidak parah.

Persentase risiko kerja pada tahap operasi bagan apung

Tahap operasi bagan apung terdiri dari aktivitas persiapan alat tangkap, pengoperasian alat tangkap, penurunan jaring (setting) dan pengangkatan jaring (hauling). Berdasarkan analisis yang dilakukan dari aktivitas tahap operasi tersebut memiliki kategori kecelakaan 92\% tidak parah, $8 \%$ parah dan $0 \%$ sangat parah (Gambar 2). Hal ini menunjukan bahwa aktivitas-aktivitas pada tahap operasi bagan apung masih memiliki risiko bahaya yang dapat mengganggu kesehatan nelayan.

Aktivitas-aktivitas pada tahap operasi bagan apung dirasa memiliki risiko dan potensi bahaya yang tinggi karena pengoperasian alat tangkap bagan apung hanya dilakukan oleh 1-2 orang nelayan. Penggunaan roller bambu sebagai alat bantu untuk menurunkan dan menaikkan bingkai jaring memang dapat mempermudah proses penangkapan bagan apung, namun ukuran roller bambu yang besar serta berat dalam menarik jaring dapat menimbulkan risiko sakit punggung serta tangan terluka. Apabila hal ini terjadi maka nelayan bagan tidak akan dapat melanjutkan aktivitas penangkapan atau membutuhkan waktu untuk memulihkan kondisi tubuh untuk kembali melanjutkan aktivitas. Penggunaan sarung tangan sebagai APD dapat meminimumkan bahaya terluka dan memberikan sedikit waktu istirahat (jeda) saat pengoperasian roller dapat meminimumkan beban pada punggung.

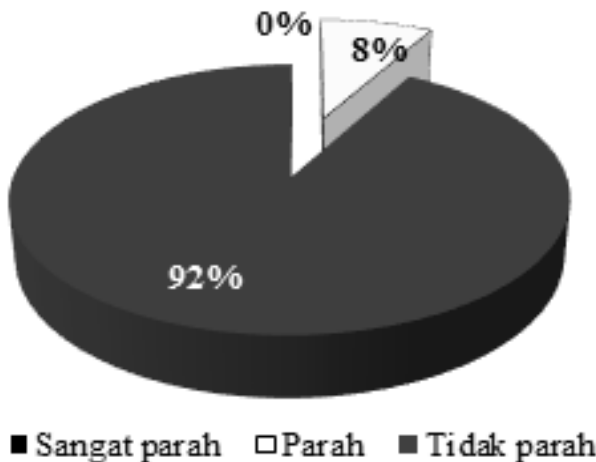

Gambar 2. Persentase risiko kerja pada tahap operasi bagan apung dari 9 kegiatan

\section{Tahap pasca operasi}

\section{Penanganan hasil tangkapan (brailing)}

Hasil tangkapan yang telah terkumpul pada jaring diambil dengan alat bantu serok dan disortir berdasarkan jenis ikan dan ukuran ikan untuk dimasukkan ke dalam keranjang-keranjang bambu yang telah dipersiapkan. Masing-masing nelayan bagan apung telah mempersiapkan keranjang-keranjang bambu berjumlah 30 keranjang/bagan apung, keranjang tersebut akan terisi penuh seluruhnya dengan hasil tangkapan apabila sedang dalam musim panen. Penyortiran hasil tangkapan biasanya membutuhkan waktu selama \pm 1 jam, setelah itu nelayan akan melepaskan jaring yang telah diangkat untuk diturunkan kembali ke perairan dan mempersiapkan kembali untuk melakukan setting selanjutnya.

Kategori kecelakaan parah tidak terdapat pada aktivitas penanganan hasil tangkapan (brailing), namun memiliki potensi bahaya dengan kemungkinan terjadi yang besar terdapat pada setiap kegiatannya yaitu tangan terluka, terbentur, dan tergelincir pada saat mengangkat dan mempersempit area jaring untuk mengambil hasil tangkapan, pengambilan hasil tangkapan menggunakan serok, dan penempatan hasil tangkapan. Kejadian tersebut dapat dicegah dengan solusi memakai APD berupa sarung 
tangan dan membersihkan jalan yang dilalui dari tercecernya hasil tangkapan. Total urutan kegiatan pada aktivitas penanganan hasil tangkapan (handling) terdapat 3 kegiatan dengan 11 potensi bahaya. Kategori kecelakaan seluruhnya termasuk ke dalam kategori kecelakaan tidak parah.

Pemindahan (loading) hasil tangkapan dan barang ke atas kapal angkut

Aktivitas dalam pemindahan (loading) hasil tangkapan yang telah didapatkan nelayan serta perlengkapan dan barang dalam pengoperasian bagan angkut ke atas kapal angkut memiliki tingkat risiko bahaya yang tinggi karena minim peralatan keselamatan dan alat bantu. Peralatan seperti genset, ember cat bekas berisi perbekalan nelayan, serta seluruh hasil tangkapan yang sudah ditempatkan dalam keranjang-keranjang bambu akan dipindahkan dari bagan apung ke atas kapal angkut oleh nelayan dibantu dengan ABK kapal yang lainnya.

Lantai bagan yang licin dapat menyebabkan nelayan dan ABK yang membantu terpeleset atau terjatuh ke laut, hal ini disebabkan lantai bagan yang licin karena basah atau bekas hasil tangkapan yang tercecer. Begitu juga dengan kapal angkut yang hendak merapat ke bagan apung seringkali menabrak dinding bagan apung yang terbuat dari bambu. Hal tersebut dapat mengakibatkan merusak atau mematahkan dinding bagan apung yang berbahan bambu tersebut.

Kategori kecelakaan parah terdapat pada kegiatan nomor 2 (dua) yaitu saat pemindahan genset dan jirigen berisi perlengkapan dari bagan apung ke atas kapal angkut, dengan potensi bahaya mesin genset atau jirigen terjatuh mengenai anggota tubuh. Kejadian tersebut dapat dicegah dengan solusi menggunakan alat bantu pengangkutan seperti katrol atau lintasan pemindahan sehingga dapat mempermudah pemindahan barang tersebut. Total urutan kegiatan pada aktivitas pemindahan (loading) dari bagan apung ke ataskapal angkut terdapat 3 kegiatan dengan 10 potensi bahaya, dalam kategori kecelakaannya terbagi atas 9 kategori kecelakaan tidak parah dan 1 kategori kecelakaan parah.

\section{Berlayar menuju pelabuhan asal (fishing base)}

Operasi penangkapan yang telah dilakukan dan hasil tangkapan yang telah ditempatkan pada keranjang bambu dari nelayan-nelayan bagan langganan akan ditempatkan pada dek kapal angkut. Aktivitas dilanjutkan dengan juru mudi mengarahkan kapal angkut menuju pelabuhan asal atau fishing base, selama perjalanan risiko bahaya yang paling menonjol ialah posisi juru mudi di atas kapal. Potensi bahaya pada posisi ini adalah juru mudi dapat tercebur ke laut karena posisi kemudi yang berada di sisi kiri kapal dan juru mudi duduk di sisi badan kapal.

Kategori kecelakaan parah terdapat pada kegiatan nomor 1 dan 3 yaitu saat nahkoda mengarahkan kapal menuju fishing base, dengan potensi bahaya kapal bocor atau tenggelam akibat terbentur badan kapal yang lain dan kapal hilang arah saat pelayaran serta saat penataan genset di dek kapal. Kejadian tersebut dapat dicegah dengan solusi melakukan pengecekan rutin terhadap kelayakan kapal, membawa alat bantu navigasi berupa GPS atau peta lokasi, serta membersihkan dek kapal yang akan dilalui. Total urutan kegiatan pada aktivitas berlayar menuju pelabuhan asal (fishing base) terdapat 3 kegiatan dengan 14 potensi bahaya. Kategori kecelakaannya terbagi atas 10 kategori kecelakaan tidak parah dan 4 kategori kecelakaan parah.

Pemindahan (unloading) hasil tangkapan dan barang ke dermaga

Pemindahan atau unloading dari atas kapal angkut bagan apung diutamakan keranjang bambu berisi hasil tangkapan yang didahulukan untuk diturunkan, karena di dermaga pelabuhan hasil tangkapan yang baru saja diturunkan dari kapal sudah ditunggu oleh pemilik bagan dan pembeli dari hasil tangkapan bagan. Aktivitas ini menimbulkan bahaya, seperti keranjang hasil tangkapan atau genset jatuh mengenai ABK atau nelayan serta keranjang berisi hasil tangkapan jatuh dan hasil tangkapan dapat berserakan.

Persentase risiko kerja pada tahap pasca operasi bagan apung

Tahap pasca operasi bagan apung terdiri dari aktivitas penanganan hasil tangkapan, pemindahan (loading) barang dan hasil tangkapan ke atas kapal angkut, berlayar kembali ke pelabuhan dan sesampainya di pelabuhan melakukan bongkar hasil tangkapan serta penurunan peralatan melaut. Berdasarkan Gambar 
3 analisis yang dilakukan dari aktivitas pada tahap pasca operasi tersebut memiliki kategori kecelakaan 88\% tidak parah, $12 \%$ parah, dan $0 \%$ sangat parah. Hal ini menunjukkan aktivitas-aktivitas pada tahap pasca operasi bagan apung dirasa masih kurang aman karena memiliki risiko dan potensi kecelakaan yang membahayakan bagi nelayan bagan.

Total persentase risiko kerja pada aktivitas bagan apung

Total persentase risiko kerja pada keseluruhan aktivitas bagan apung memiliki kategori kecelakaan dari 115 kegiatan tidak parah, 16 kegiatan parah dan tidak ada kegiatan yang berkategorikan sangat parah. Gambar 4 menjelaskan, persentase dari risiko kerjanya yaitu $88 \%$ tidak parah, $12 \%$ parah dan 0\% sangat parah.

Bahaya merupakan segala sesuatu yang mempunyai kemungkinan mengakibatkan kerugian baik pada harta benda, lingkungan, maupun manusia (Budiono 2003). Potensi bahaya yang ada dalam operasi bagan apung mengarah kepada kecelakaan pribadi seperti tangan terluka, tersandung, tergelincir dan yang lainnya merupakan bahaya yang diakibatkan karena properti (barang) atau karena faktor lingkungan kerja. Oleh karena itu dari seluruh potensi risiko bahaya yang ada maka dapat dicegah dan diminimalkan dengan penggunaan APD berupa sarung tangan, warepack, life jacket, dan penggunaan sepatu atau alas kaki.

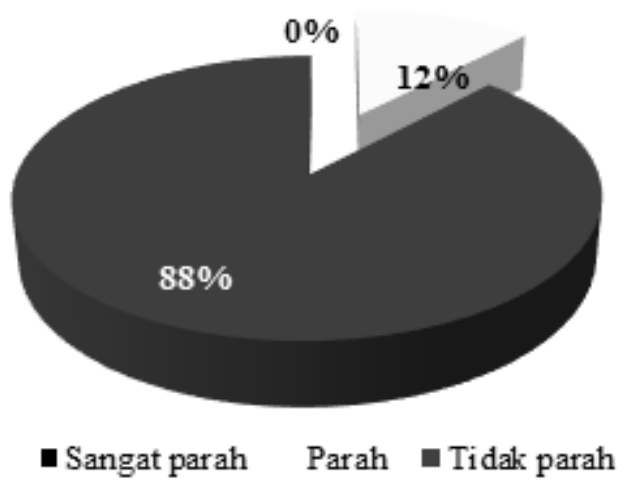

Gambar 3. Persentase risiko kerja pada tahap pasca operasi bagan apung dari 13 kegiatan

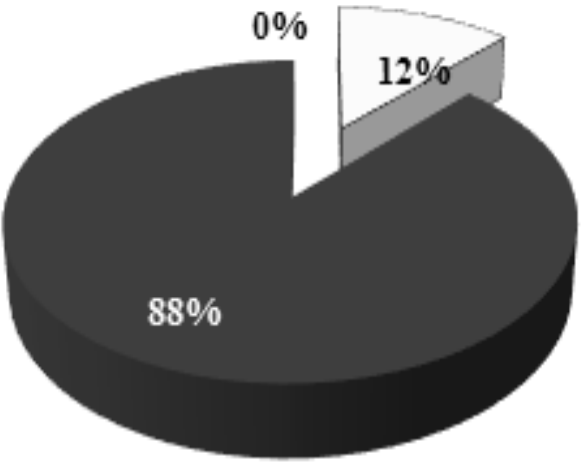

- Sangat parah $\square$ Parah Iidak parah

Gambar 4. Persentase total risiko kerja bagan apung dari 40 kegiatan 


\section{Analisis keselamatan kerja bagan apung}

Berdasarkan hasil JSA yang telah dilakukan maka di dapatkan aktivitas dan kegiatan yang memiliki potensi kecelakaan kerja pada keseluruhan rangkaian perikanan bagan apung di Palabuhanratu. Hasil perhitungan keseluruhan aktivitas telah dibagi ke dalam 3 (tiga) tahapan proses yaitu pra operasi, operasi, dan pasca operasi. Tahapan yang memiliki potensi kecelakaan kerja paling tinggi ialah pada tahap pra operasi.

Tahap pra operasi memiliki 5 aktivitas besar yang diuraikan menjadi 18 kegiatan, dari 18 kegiatan itu didapatkan 56 potensi kecelakaan kerja yang selanjutnya akan dibagi ke dalam 3 kategori kecelakaan. Kategori kecelakaan yang dimaksud adalah kategori kecelakaan sangat parah, parah, dan tidak parah. Tahap pra operasi memiliki nilai paling tinggi di dalam kategori kecelakaannya, dibandingkan dengan tahap operasi dan pasca operasi.

Kategori kecelakaan sangat parah dalam keseluruhan tahapan memang tidak ditemukan atau memiliki nilai 0 (nol) di seluruh tahapan.Dalam hasil pengamatan langsung pada tahapan aktivitas di bagan apung, dari keberangkatan di pelabuhan (fishing base) hingga kembali ke pelabuhan tidak ditemukan adanya potensi kecelakaan yang dapat menimbulkan korban jiwa bahkan sampai meninggal dunia. Kategori kecelakaan parah pada tahap pra operasi memiliki nilai 8, nilai ini merupakan yang tertinggi dibandingkan dengan nilai pada tahap operasi dan tahap pasca operasi. Masing-masing tahapan ini memiliki nilai 2 dan 6. Kategori kecelakaan tidak parah pada tahap pra operasi memiliki nilai 48 , tahap ini tetap memiliki nilai paling tinggi dibandingkan dengan tahap operasi yang memiliki nilai 23 dan tahap pasca operasi yang memiliki nilai 44 .

Penilaian tersebut menunjukkan bahwa kegiatan-kegiatan yang terdapat pada tahap pra operasi seharusnya menjadi perhatian khusus bagi nelayan bagan maupun juru kapal agar potensi kecelakaan tersebut dapat diminimalkan. Hal ini dikarenakan keseluruhan kegiatan dalam tahap ini hanya berisikan tentang kegiatan di darat pada saat persiapan sebelum berangkat melaut.

\section{Pengetahuan nelayan bagan apung tentang keselamatan kerja}

Nelayan bagan merupakan nelayan tradisional yang dominan mengoperasikan bagan apung. Para nelayan ini berpindah dari bagan tancap yang sebelumnya cukup populer, setelah adanya himbauan dari pemerintah mengenai bagan tancap yang memberikan dampak negatif bagi sistem pelayaran laut. Selain bagan apung dapat mengurangi dampak negatif tersebut, bagan apungjuga dinilai lebih efisien jika digunakan oleh nelayan setempat, dikarenakan alat tangkap bagan apung dapat dipindahpindahkan lokasinya sesuai dengan daerah penangkapan pada musim tertentu serta keinginan dari nelayan bagan tersebut. Bagan apung dioperasikan di sekitar Teluk Palabuhanratu yang dapat ditempuh dalam 2-3 jam perjalanan laut atau sekitar \pm 25 mil laut dari fishing base (PPN Palabuhanratu).

Risiko kecelakaan yang dirasa cukup tinggi pada saat operasi penangkapan ikan pada alat tangkap bagan apung dibagi dalam 3 tahap aktivitas yaitu pra operasi, operasi, dan pasca operasi. Keseluruhan tahapan tersebut belum menjadi fokus utama oleh nelayan, pemilik kapal, ataupun instansi pengelola pelabuhan. Nelayan setempat cenderung berani mengambil keputusan untuk tidak terlalu memperhatikan risiko bahaya dan kecelakaan kerja dikarenakan adanya berbagai alasan yang beragam seperti kurangnya kemampuan ekonomi, kurangnya pemahaman mengenai keselamatan kerja dan alat keselamatan kerja yang harus digunakan, dan dalam melakukan aktivitas penangkapan sehari-hari nelayan hanya bertindak berdasarkan pengalaman dan pemahaman bahwa penggunaan alat keselamatan tidaklah penting, sehingga hal tersebut menjadi sebuah paradigma bagi nelayan bahwa keselamatan di laut tergantung kepada pribadi masing-masing orang untuk mempertahankan dirinya apabila ada bahaya yang mengancam.

Nelayan hanya mengandalkan pengalamannya untuk melaut berdasarkan melihat tanda-tanda dari alam sebelum berangkat melaut untuk mengantisipasi adanya bahaya yang dapat mengancam apabila hendak pergi melaut tanpa melengkapi alat keselamatan yang sesuai dengan kondisi dan pekerjaannya. Sistem peringatan dini yang ada di PPN Palabuhanratu berupa papan informasi angin, kecepatan angin, dan cuaca serta peringatan dini untuk tsunami pun kurang dapat dimanfaatkan dengan baik oleh nelayan. Hal ini disebabkan kurangnya pemahaman nelayan untuk memanfaatkan 
informasi dan adanya keterbatasan yang disampaikan oleh sistem peringatan dini tersebut, seperti kurangnya kemampuan nelayan untuk membaca informasi yang diberikan oleh papan informasi tersebut, kurangnya kepedulian nelayan untuk mendapatkan informasi tentang kondisi perairan dan cuaca, serta minimnya informasi yang ditampilkan oleh papan informasi tersebut karena terkadang informasi yang diberikan kurang akurat dan tidak selalu diperbaharui dengan kondisi terbaru. Alat keselamatan yang dibawa oleh nelayan bagan apung hanyalah ember kaleng cat bekas berisi perbekalan dan peralatan melaut yang sekaligus berfungsi sebagai alat pelampung apabila terjadi kecelakaan sehingga menyebabkan nelayan tercebur ke laut. Selanjutnya hanya telepon genggam yang digunakan sebagai alat komunikasi utama karena jarak melaut yang dirasa masih relatif dekat dan sinyal telepon genggam masih menjangkau daerah operasi bagan apung tersebut.

Jenis kecelakaan yang pernah terjadi di atas kapal angkut dan alat tangkap bagan apung pada saat melaut di dominasi dengan kapal tenggelam, terbalik, hanyut, serta kecelakaan kerja. Kejadian kebakaran dan tubrukan sangat jarang terjadi pada kapal angkut di sekitar Teluk Palabuhanratu. Gambar 5 menunjukkan hasil wawancara kuesioner terhadap nelayan bagan apung di PPN Palabuhanratu, serta Gambar 6 sebagai hasil wawancara terhadap juru mudi dan ABK kapal angkut bagan seputar jenis kecelakaan yang sering terjadi di atas alat tangkap bagan apung dan kapal angkut.

Berdasarkan Gambar 5 terlihat bahwa dari 30 responden nelayan terkait kecelakaan yang sering terjadi di bagan apung di dapatkan kasus kecelakaan yang sering terjadi ialah hanyutnya bagan apung yang disebabkan oleh putusnya tali jangkar dan terkena badai saat musim barat. Selanjutnya potensi kecelakaan yang sering terjadi adalah bagan tenggelam dikarenakan pelampung yang rusak atau kerangka bangunan bagan yang berbahan bambu sudah mengalami pelapukan atau sudah melewati umur teknisnya. Kecelakaan kerja pada saat pengoperasian bagan juga sering terjadi akibat kelalaian nelayan yang tidak melengkapi dirinya dengan APD yang seharusnya digunakan untuk meminimalkan risiko bahaya saat kerja.

Berdasarkan Gambar 6 menunjukkan bahwa potensi kecelakaan yang sering terjadi adalah hanyut yang disebabkan oleh mesin kapal mati atau rusak akibat tidak adanya pengecekan mesin kapal secara rutin. Selanjutnya potensi yang sering terjadi adalah tenggelam dan tubrukan. Kecelakaan kerja juga dikatakan memiliki potensi kecelakaan kerja yang tinggi karena seluruh awak kapal termasuk juru mudi, ABK, serta nelayan bagan yang ikut dalam pelayaran kapal tidak melengkapi dirinya dengan APD berupa life jacket dan kapal angkut juga tidak dilengkapi dengan alat keselamatan yang seharusnya wajib dimiliki oleh kapal yang melakukan operasi di laut. Peralatan yang termasuk dalam safety equipment pada kapal yang di kemukakan oleh IMO (International Maritime Organization) pada tahun 1960 adalah dokumen (documentation), peralatan navigasi (safety of navigation), perlengkapan penyelamat jiwa (life saving appliances), pompa pemadam, hidran, selang dan alat pemadamm (fire pumps, hydrants, hoses, and extinguishers), perlengkapan pemadam kebakaran untuk ruang muat (fire appliances in cargo space), serta perlengkapan pemadam lain (other fire appliances). Peralatan keselamatan yang digunakan nelayan adalah jirigen dan ban bekas yang digunakan sebagai pelampung apabila terjadi kecelakaan pada kapal angkut bagan.

Menurut PP RI No.50 Th.2012 tentang Penerapan Sistem Manajemen Keselamatan dan Kesehatan Kerja, K3 adalah segala kegiatan yang menjamin keselamatan dan kesehatan tenaga kerja melalui upaya pencegahan kecelakaan kerja dan penyakit akibat kerja. Menciptakan sistem keselamatan kerja tentunya harus didukung oleh keterampilan dan pengetahuan yang wajib dimiliki orang-orang yang terkait di dalamnya. Gambar 7 menunjukkan hasil wawancara terhadap nelayan bagan apung di PPN Palabuhanratu mengenai pengetahuan tentang keselamatan kerja, pengetahuan mengenai aturan keselamatan kerja, pengetahuan akan pentingnya prosedur kerja di atas kapal, dan kesadaran nelayan akan keselamatan kerja.

Hasil wawancara yang disajikan pada Gambar 7 menunjukkan bahwa nelayan yang memiliki pengetahuan mengenai keselamatan kerja hanya sebesar $30 \%, 37 \%$ nelayan sedikit mengetahui tentang keselamatan kerja dan 33\% tidak mengetahui mengenai keselamatan kerja. Adanya aturan mengenai keselamatan kerja hanya diketahui oleh $16 \%$ nelayan dan $27 \%$ sedikit tahu tentang aturan tersebut yang hanya sebatas mengetahui tetapi tidak 
dapat menyebutkan aturan yang berlaku, namun yang menjadi permasalahan adalah $57 \%$ nelayan sama sekali tidak mengetahui adanya aturan mengenai keselamatan kerja yang seharusnya mereka pahami dan diterapkan dalam melakukan operasi penangkapan.

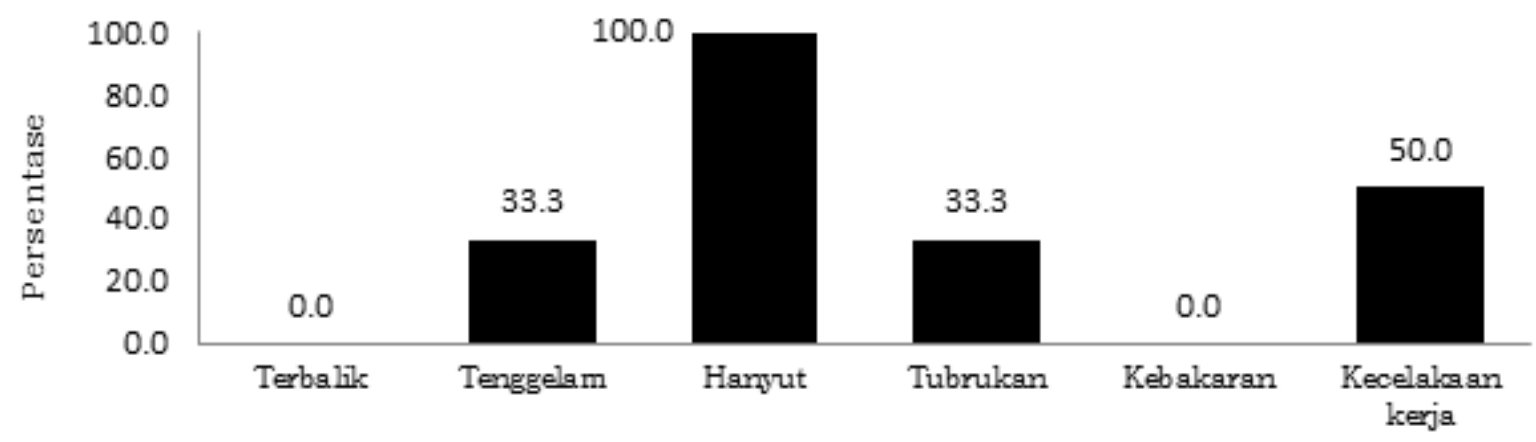

Gambar 5. Hasil wawancara terhadap nelayan terkait kecelakaan yang sering terjadi di alat tangkap bagan apung (Sumber: Hasil Wawancara terhadap Nelayan)

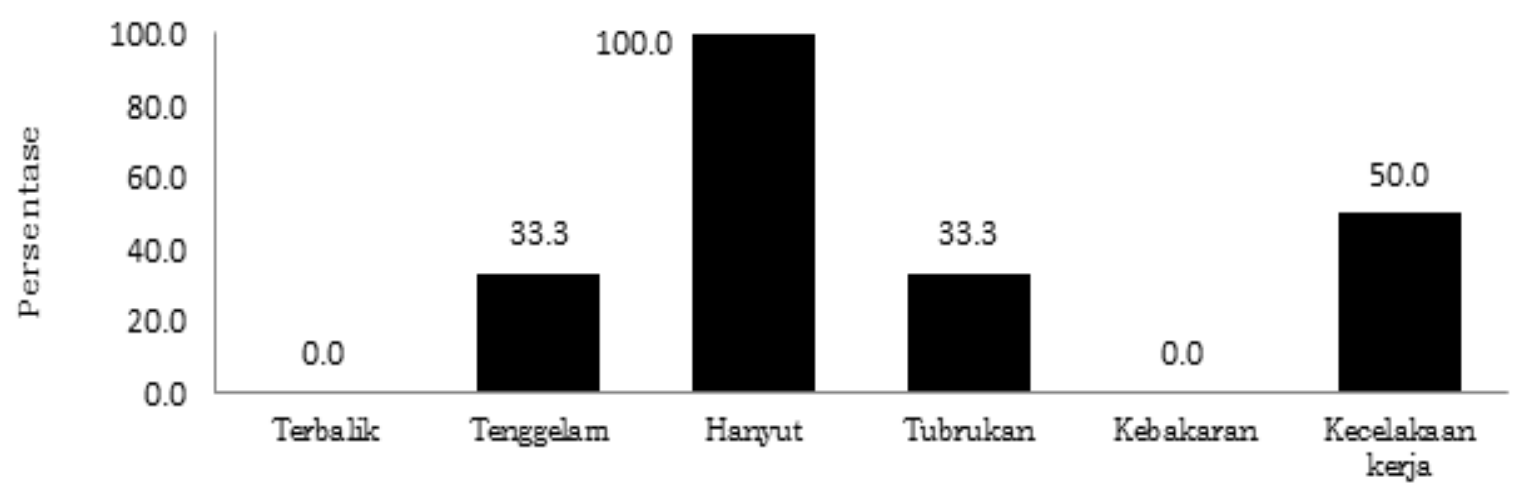

- Prosentase kejadian kecelakaan yang sering terjadi di kapal angkut bagan

Gambar 6. Hasil wawancara terhadap juru mudi dan ABK kapal terkait kecelakaan yang sering terjadi di kapal angkut bagan (Sumber: Hasil Wawancara terhadap Juru Mudi dan ABK Kapal Angkut (diolah))

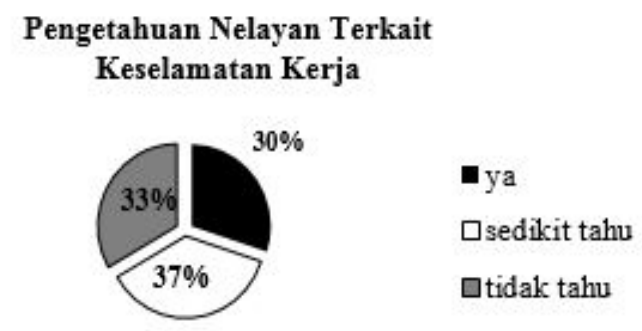

Pengetahuan Mengenai Pentingnya Prosedur Kerja di Atas Kapal





Kesadaran Nelayan Akan Keselamatan Kerja

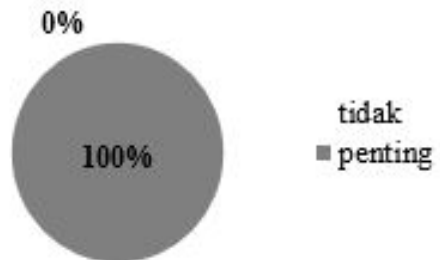

Gambar 7. Pengetahuan dan kesadaran terkait keselamatan kerja (Sumber: Hasil wawancara terhadap nelayan (diolah)) 
Mayoritas nelayan banyak yang tidak mengetahui dan kurang memahami mengenai peraturan keselamatan kerja di laut dan prosedur kerja yang ada. Prosedur kerja yang ada seharusnya ditaati oleh pekerja di atas kapal. Menurut BAKORKAMLA (2009) dalam buku pedoman khusus keselamatan dan keamanan pelayaran adalah sebagai berikut, nahkoda bertanggung jawab terhadap keselamatan pelayaran kapal yang dipimpin/ditangani, pada saat tugas jaga, Mualim I (Chief Officer) bertanggung jawab terhadap pelayaran yang aman. Mualim I harus membantu Nahkoda sebagai pimpinan di atas kapal, nahkoda dan Mualim I diperlengkapi dengan peralatan alat bantu navigasi untuk membantu memastikan pelayaran kapal yang aman. Alat bantu tersebut tidak akan efektif dan bahkan bisa menimbulkan bahaya kalau tidak digunakan dengan benar sesuai dengan kemampuan dengan keterbatasannya. Sedapatnya bila memungkinkan posisi kapal yang didapat dengan satu cara, harus selalu diperiksa dengan cara yang lain. Pelampungpelampung (buoys) bisa bergeser dari posisinya dan tidak bisa dijadikan sebagai patokan penentu posisi kapal, adalah bahaya menggunakan petunjuk otomatis (automatic pilot) pada perairan yang padat dengan daratan dan perjalanan pendek. Jadi alat tersebut tidak perlu digunakan, peraturan internasional tentang pencegahan tubrukan di laut harus selalu dipatuhi, nahkoda harus menulis perintah berjalan (standing order) dengan jelas dan tepat dan ditandatangani, serta diberi tanggal yang disediakan Mualim I dan semua personel kapal harus beristirahat dengan cukup sebelum melakukan tugas jaga. Tugas jaga tidak harus diserahterimakan kalau petugas jaga pengganti kurang sehat secara medis.

Prosedur tersebut seharusnya dijalankan demi terciptanya keselamatan dan keamanan. Namun kenyataannya di lapangan hanya $13 \%$ nelayan yang tahu dan menjalankan beberapa prosedur dengan baik, dan 30\% nelayan yang sedikit tahu serta $57 \%$ nelayan yang tidak mengetahui sehingga dapat disimpulkan bahwa nelayan yang menjalankan prosedur di atas kapal masih sangat minim. Prosedur yang ditulis dalam buku pedoman tersebut sangat sulit diimplementasikan oleh kapal angkut bagan di PPN Palabuhanratu, karena awak kapal yang berjumlah dua orang sehingga prosedur tersebut tidak dapat diaplikasikan dalam pelayaran di lapangan. Menurut instansi pemerintah setempat yang bertanggung jawab atas terciptanya kesehatan dan keselamatan kerja serta menunjang keamanan laut, diperlukan sebuah komite keamanan laut yang di dalamnya merupakan instansi dan organisasi yang berperan aktif dalam langkah mencegah kecelakaan di laut. Instansi-instansi yang berwenang dalam hal ini yakni Ditpolair, Syahbandar/Dinas Perhubungan Laut, Pemerintah Daerah, Dinas kelautan dan Perikanan, Badan Meteorologi, Klimatologi, dan Geofisika (BMKG), Kesatuan Penjaga Laut dan Pantai (KPLP), Komite Nasional Keselamatan Transportasi (KNKT), serta dinas kesehatan.

Walaupun pengetahuan nelayan seputar keselamatan kerja dirasa sangat minim, namun $100 \%$ nelayan sangat sadar akan pentingnya keselamatan kerja. Hal tersebut dibuktikan dengan adanya beberapa aplikasi mengenai alat keselamatan yang tanpa disadari telah disiapkan dan dilengkapi oleh nelayan setempat, walau alat keselamatan tersebut hanyalah peralatan pengganti atau alternatif dari alat keselamatan yang terdapat pada peraturan nasional maupun internasional.

\section{KESIMPULAN DAN SARAN}

\section{Kesimpulan}

Pengoperasian bagan apung di Palabuharatu, Sukabumi terdiri dari 15 aktivitas, yang dikelompokkan ke dalam 3 tahapan (pra operasi, operasi, dan pasca operasi.). Hasil pengamatan dari keseluruhan aktivitas bagan apung di atas teridentifikasi memiliki potensi bahaya di setiap kegiatannya. Hasil analisis keselamatan kerja atau JSA menunjukkan bahwa risiko yang timbul terbagi dalam 3 kategori kecelakaan yakni kategori tidak parah memiliki presentase $88 \%$ potensi bahaya, kategori parah memiliki presentase $12 \%$ potensi bahaya, dan kategori sangat parah bernilai $0 \%$ potensi bahaya dan nelayan memiliki pengetahuan yang sudah dikategorikan cukup baik mengenai keselamatan kerja dan prosedur kerja di kapal.

\section{Saran}

Saran yang dapat dikemukakan penulis untuk perbaikan penelitian ini, yaitu sosialisasi tentang penerapan keselamatan kerja di atas kapal yang sudah atau belum berjalan oleh PPN Palabuhanratu disarankan 
lebih tepat sasaran, salah satunya kepada nelayan bagan apung serta awak kapal angkut bagan dan perlu dilaksanakan sosialisasi dan pelatihan keselamatan kerja oleh pihak pemerintah dan instansi terkait, atau berupa papan-papan himbauan serta spanduk tentang K3 (Kesehatan dan Keselamatan Kerja), sehingga nelayan memiliki kompetensi kerja yang memadai dalam melakukan operasi penangkapan ikan.

\section{DAFTAR PUSTAKA}

Adi B S, Djaya I K. 2008. Nautika Kapal Penangkap Ikan Untuk SMK Jilid 2. Jakarta (ID): Direktorat Pembinaan Sekolah Menengah Kejuruan, Direktorat Jenderal Manajemen Pendidikan Dasar dan Menengah, Depatemen Pendidikan Nasional.

Ant. Senin, 23 Maret 2009. Pemerintah Mesti Memperhatikan Nasib Nelayan Tradisional. Bali (ID): Bali Post. Hal 17 Kolom 5.

[BAKORKAMLA] Badan Koordinasi Kemanan Laut. 2009. Pedoman Khusus Keselamatan dan Keamanan Pelayaran. Jakarta (ID): BAKORKAMLA.

Budiono, S. A. M. 2003. Manajemen Risiko dalam Hiperkes dan Keselamatan Kerja Bungan Rampai Hiperkes \& KK Edisi Kedua. Semarang (ID) : Universitas Diponegoro. www.ccohs. ca/oshanswers/hsprograms/job-haz. html

[CCOHS] Canadian Centre for Occupational Health and Safety. 2008. Job Safety Analysis [internet]. www.ccohs.ca/ oshanswers/hsprograms/job-haz. html

Cross, J. 1998. Study Notes SESC9211 "Risk Management". Departemen of Safety Science University of New South Wales
(UK).

Effendi I. 2002. Pengaruh Penggunaan Rumpon pada Bagan Apung Terhadap Hasil Tangkapan. [skripsi]. Bogor (ID) : Pemanfaatan Sumberdaya Perikanan FPIK IPB.

[FAO] Food and Agriculture Organization. 2009. The State of World Fisheries and Aquaculture 2008. Rome, Italy (IT).

[IMO] International Maritime Organization. 1960. International Convention for the Safety of Life at Sea. London (UK).

[IMO] International Maritime Organization. 2007. Safety of Fishing Vessel. London (UK).

Pemerintah Republik Indonesia. 2012. Peraturan Pemerintah Republik Indonesia. Nomor 50 Tahun 2012 Tentang Penerapan Sistem Manajemen Keselamatan dan Kesehatan Kerja. Jakarta (ID): Sekretariat Negara.

Purwangka F. 2013. Keselamatan Kerja Nelayan Pada Operasi Penangkapan Ikan Menggunakan Payang di Palabuhanratu, Jawa Barat.[disertasi]. Bogor (ID): Institut Pertanian Bogor. $132 \mathrm{hlm}$.

Soeripto IR. 1997. Job Safety Analysis. Hiperkes dan Keselamatan Kerja. Volume 31(1). Jakarta (ID).

Subani, Barus. 1989. Alat Penangkapan Ikan dan Udang Laut di Indonesia. Jurnal Perikanan Laut Nomor: 50 Th. 1988/1989 edisi khusus. Jakarta (ID): Departemen Pertanian, Balai Penelitian Perikanan Laut. 248 hlm.

Suma'mur. 1995. Hygiene Perusahaan dan Kesehatan Kerja. Jakarta (ID): Gunung Agung.

Wyrtki, Klaus. 1961. The thermohaline circulation in relation to thr general circulation in the oceans. Deep-Sea Research, 1961, Vol. 8. Pergamon Press Ltd. London. 